\title{
原料輸送管防食経過ならびに防食測定報告*
}

\author{
吉川 洋 ${ }^{* *}$ 中村清治 ${ }^{* *}$ 後藤俊介*** 早川武夫***
}

\section{Underground Corrosion Tests on Cathodically Protected Coated Pipeline}

Hiroshi Yoshikawa, Kiyoji Nakamura, Syunsuke Gotô and Takeo Hayakawa

\begin{abstract}
A series of underground corrosion tests has been carried out in order to supply corrosion data as well as basis for estimating life of a pipeline transporting raw material gases to a butadiene plant at Yokkaichi-Combinat. The protection procedure of the line was based on the recommendation of Corrosion Prevention Committee, Japan Society for the Promotion of Science.
\end{abstract}

Total of 144 test pieces was buried near the warf which was considered to be the most corrosive environment in the pipeline area. The coated steel specimens were connected to the cathodically protected pipeline. Some specimens were not cathodically protected.

The seven-year results show among others that cathodic protection is especially effective in reducing corrosion of bare part of coated steel, which otherwise corrodes $5 \sim 10$ times. The tests will be continued up to 20 years.

\section{1. まえがき}

日本合成ゴム（株）が四日市にスチレンブタジェン合 成ゴム工場を建設するにあたって，各種原料の供給を四 日市の三菱油化, 昭和四日市石油, 大協石油の各工場か ら受けるために原料輸送用地下配管を敷設した。

配管を市街地に埋設する関係上, 種々の問題点があり, 通産省が主に腐食防止対策について日本学術振興会およ び電気学会電食防止研究委員会埋設鉄管防食小委員会等 に図るよう要求された。よって日本学術振興会に図り, 腐蝕防止第 97 委員会から昭和 34 年秋にその答申を受 け，この内容に沿って腐食防止対策は日本防蝕工業（株） の実地調査, 対策立案および実施, 塗覆装ならびに配管 は千代田化工建設（株）の担当で行なった。

なおこれと併行して塗覆装劣化状態および鋼管耐用年 数の確認のためにテストピースを 144 個埋設し, 20 年 間にわたって検査を行ならことになった。その概要は既 に昭和 37 年 7 月学振第 97 委員会にて発表1) 済みであ るが, 現在工事施工後約 9 年を経過し， 7 年目までのデ 一タが得られた。よって前回の発表と一部重複するが第

97 委員会の答申と工事の概要を添えて中間報告を行な 5。

\section{2. 日本学術振興会腐蜻防止第 97 委员会の答申の要約}

* 昭和 43 年 10 月 17 日第 15 回腐食防食討論会 (北九州市) で発表

** 日本合成ゴム(株)四日市工場（四日市市川尻町 100）

*** 日本防蝕工業(株) (東京都千代田区丸ノ内 1-1)

\section{$2 \cdot 1$ 適当な鉣復装}

環境が臨海地帯であることを考慮し，鋼管の外面は当 然高度の塗覆装を必要とする。したがって米国の AWW $\mathrm{A}$ 規格（または電食防止研究委員会鉄管塗覆装分科会に おいて成案を得た塗覆装基準案）に準拠し十分な厚みを 有するコールタールエナメル質またはアスファルトエナ メル質の塗覆装を施すことを要する。

\section{$2 \cdot 2$ 垐覆装の検查方法}

ホリデイディテクターにより A.C. 8,000〜10,000 V のスパーク試験を実施する。

\section{$2 \cdot 3$ 垐夏装管路に対する電気防食の必要性}

塗覆装欠陷部および現場溶接部近傍に腐食が起こり易 いので，これを防止するためには良質な塗覆装を施した 管路に対しても電気防食を適用することが必要と考えら れる。この場合は鋼管外面の大部分が被覆されている関 係上，僅少な防食電流で十分な防食効果が得られるので 有利である。

\section{4 適当な電気防食施工方式と調整方法}

塗覆装が良質であること, 土壤比抵抗が低いことから 外部電源方式より流電陽極方式の方が適当と思われる。 また対象管と非対象管との電気的絶縁については万全を 期するよう考虑することが望ましい。なお管路は電鉄軌 条に平行あるいは交叉するので, 排流等の方法により電 食防止を行ならと同時に管路の防食効果を向上させるよ ら調整する。

\section{5 笑防食効果の確跑方法}


全管路にわたり各部の防食状態を点倹するには，現在 各国で採用されている電位分布の測定によるのが最も適 当と認められる。したがって管路の電位を実測し，飽和 硫酸銅電極に対して $-850 \mathrm{mV}$ の防食電位もしくはそれ より卑值にあることを確かめることが適当な方法である。

\section{$2 \cdot 6$ 染覆装劣化状態および鋼管耐用年数の確認方法}

測定方法は鋼管試験片を管路近傍の土中に埋設し, 所 定期間後に堀出して調査することにより劣化ないし侵食 度を判定することが適当と考学られる。試験片としては 塗覆装と無塗装のもの相当数を埋設し鋼管路に接続して 同電位に保持し電気防食効果を反映させるとともに, 一 部の試験片は管路と連結しないで土中の自然の变化を表 わすようにする。

\section{3. 原料輸送管路ならびに防食装置の概略}

\section{1 管径および長さ}

$2 \mathrm{~B}, 3 \mathrm{~B}, 6 \mathrm{~B}$ 全長 $35,250 \mathrm{~m}$ (図 1)。

\section{$3 \cdot 2$ 管路塗覆装}

アスファルトプライマー, ブロンアスファルト $3 \mathrm{~mm}$, ガラスクロス $0.14 \mathrm{~mm}$, ブロンアスファルト $3 \mathrm{~mm}_{\circ}$

\section{3 電気防食装置}

管路の土壤腐食ならびに電鉄軌条からの迷走電流によ る䉓食を防止するために，マグネシウム陽極を使用する 流電陽極方式と選択排流方式とを併用して取り付けた。

マグネシウム陽極取付個数：

$$
\begin{array}{r}
\text { 17-D型 } 49 \text { 本 (15 個所に分散設置) } \\
\text { 5一 L 型 } 248 \text { 本 }(34 \text { 個所に分散設置) }
\end{array}
$$

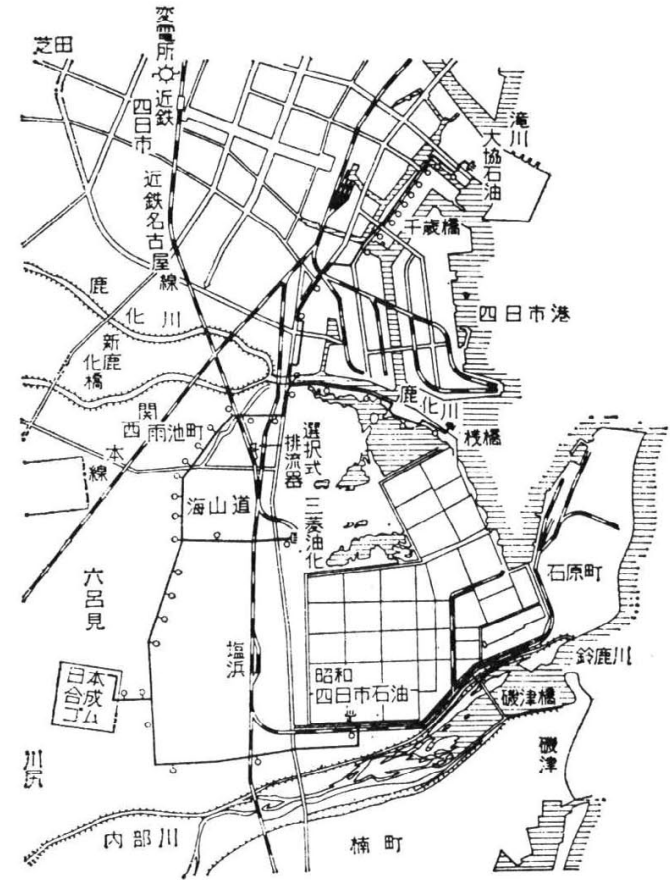

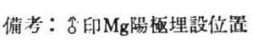
$0 . \quad 500 \quad 1000 \mathrm{~m}$

図 1 日本合成コム四日市工場構外輸送管一般平面図 そのほか道路横断部などの䩗管部分は内部管路の防食に 万全を期するために，線状の $\mathrm{Mg}$ 陽極ガルボラインを

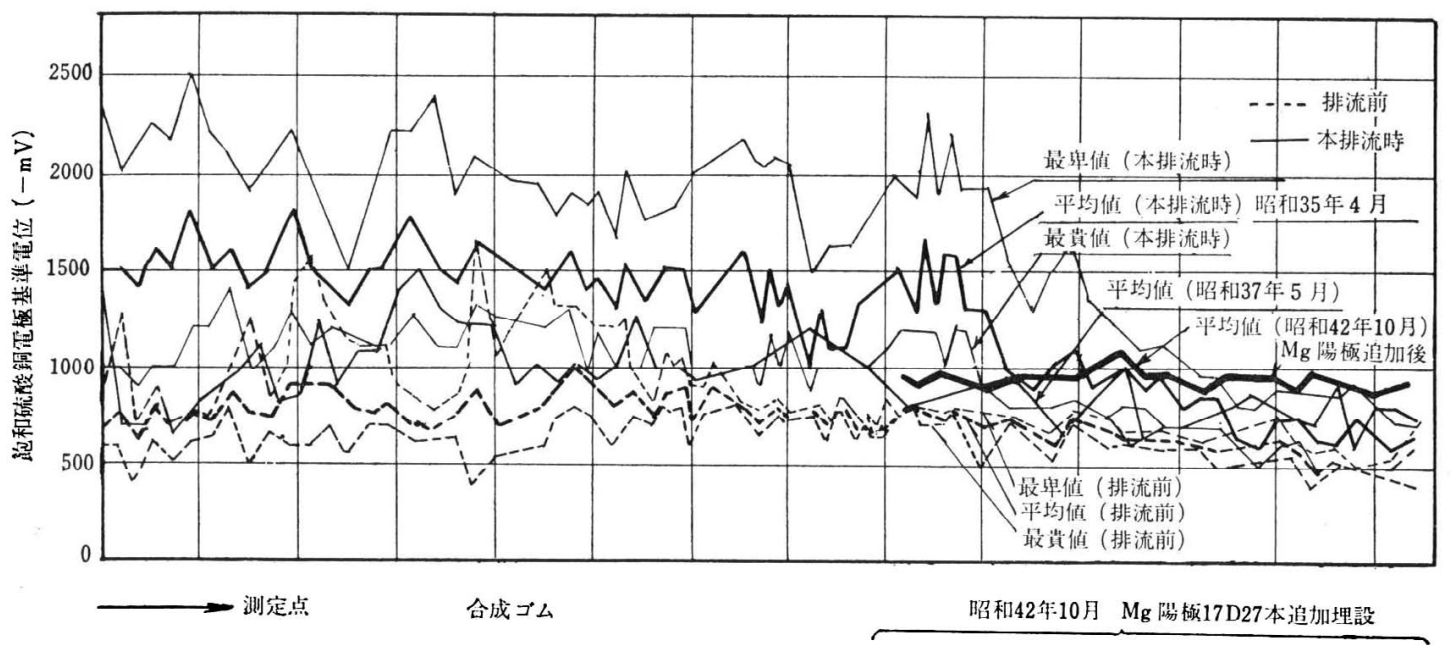

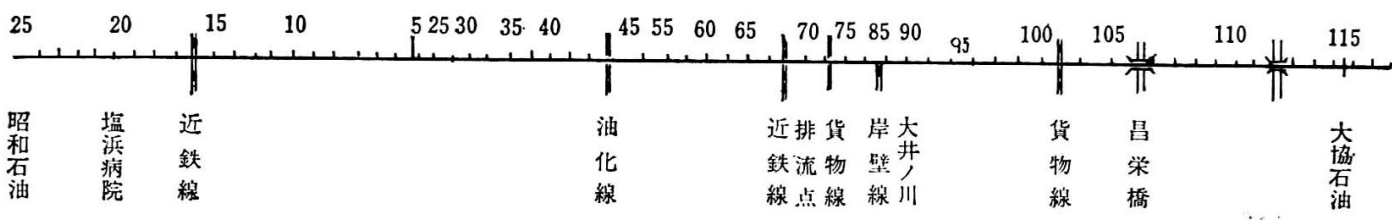

図 2 原料輸送用地下配管対地電位分布図 
総延長 $808 \mathrm{~m}$ 挿入し管路と接続した。

絶縁接手取付個数 :

2 B 3 B 圧力 $150 \sim 300 l b 22$ 組

管相互のボンド個所数 :

20 個所

なおこれら防食装置の計画は, 事前に行なった予備調 查（土壌比抵抗測定，軌条対地電位ならびに電流方向測 定, 土壤 $\mathrm{pH}$ の測定, 排流試験）の結果によって行なっ た。

\section{4. 防食効果の確認}

管対地電位測定結果を図 2 に示す。都市の発展に伴い 環境には大さな変化があったが，終始良好な状況に保持 されるように管理を行なっている。

なおこれとは別にテストピースの埋設を行ない, 経時 的な防食効果の試験を行なった。

\section{5. テストピース埋設ならびに防食状況の検查経過}

\section{$5 \cdot 1$ 試験場所}

日本合成ゴム構内および岸壁線末端バルブ付近（海水 の影響を受ける悪条件区域）

\section{$5 \cdot 2$ 試験 期間}

テストピース埋設後 $1,2,3,5,7,10,13,16,20$ 年ごとに合計 9 回にわたり掘出し検査。

\section{$5 \cdot 3$ テストピースの形状および数量}

材質：配管と同質, STP-38, Sch 40, 2 B。

構造：鋼管の両端を鋼板でふさぎ，一端にリード線を 取り付けたもの。
塗装 : 配管と同塗装，らち半数は中央部 $50 \mathrm{~mm}$ 幅を 裸とした。

個数：通電，不通電とに分け，合計 144 個。

\section{4 検查結果ならびに考察}

3 年目， 5 年目および 7 年目の計測結果を表 1 , 表 2 および表 3に示す。また各年度の実際の腐食量を图 3, および図 4 に，防食率ならびに年間平均腐食量を図 5 お よび図 6 に示す。

1）実測値にはかなりのばらつきがあるが，これは試 験片の仕上げ方のバラッキ, 重量計測值の不正確などが 考えられ，予想以上に大きくなっている。傾向としては 2 年目と 3 年目が特に高い腐食量を示している。

2）腐食量は経年とともに一般に鈍化の傾向にある。

3） 入念に行なった塗覆装は防食に対して非常に効果 的である。

4）試験片の実際の腐食減量について合理的な性能の 比較は困難であるが，次のような傾向が認められる。

a ）裸面のある不通電試片は裸面のある通電試片に比 ベて明らかに 5〜10 倍の腐食を示している。

b ）裸面のある通電試片は構内側が岸壁側の 2 倍前後 になっている。

c）全面塗装のものは通電，不通電ともに岸壁側の裸 面のある通電試片と大差ない値を示している。

d）全面塗装のものについては一, 二の例外を除くと, 順位としては腐食の大きいものから岸壁側の不通電, 岸 壁側の通電, 構内側の不通電, 構内側の通電の順になっ

表 13 年目計 测 結 果

昭和 38 年 3 月 $16 \sim 19$ 日測定

\begin{tabular}{|c|c|c|c|c|c|c|c|c|c|c|c|c|c|}
\hline \multirow{2}{*}{$\begin{array}{l}\text { 場 } \\
\text { 所 }\end{array}$} & \multirow{2}{*}{$\begin{array}{l}\text { ティト } \\
\text { ピース } \\
\text { No. }\end{array}$} & \multirow{2}{*}{ 洤装状況 } & \multirow{2}{*}{$\mid$} & \multirow{2}{*}{$\begin{array}{l}\text { 埋設 } \\
\text { 状洗 }\end{array}$} & \multirow{2}{*}{ 被覆状況 } & \multirow{2}{*}{ 外面検査 } & \multirow{2}{*}{$\mid \begin{array}{c}\text { ピッティング } \\
\text { 梁さ最大 } \\
\text { (mm) }\end{array}$} & \multicolumn{3}{|c|}{ 測 } & \multirow{2}{*}{$\begin{array}{l}\text { 侵 食度 } \\
(\mathrm{mm} / \mathrm{yr})\end{array}$} & \multirow{2}{*}{$\begin{array}{l}\text { 腐 食量 } \\
\left(\mathrm{g} / \mathrm{m}^{2} \cdot \mathrm{yr}\right)\end{array}$} & \multirow{2}{*}{ 備考 } \\
\hline & & & & & & & & $\begin{array}{l}\text { 埋設時 } \\
(\mathrm{g})\end{array}$ & $\begin{array}{c}3 \text { 年後 } \\
(\mathbf{g})\end{array}$ & (差) & & & \\
\hline \multirow{5}{*}{ 構 } & 17 & 全 面 & 通電 & 良 & 正 常 & 不 & - & 750.270 & 749.761 & $|-0.509|$ & 0.00086 & 6.78 & \\
\hline & 18 & " & 否 & $"$ & 凸凹变形 & " & - & 739.685 & 739. 396 & -0.289 & 0.00049 & 3.853 & \\
\hline & 65 & " & 通電 & " & 正 常 & " & - & 768.505 & 768.036 & -0.469 & 0.00079 & 6.26 & \\
\hline & 66 & " & 否 & " & 凸凹变形 & " & - & 761.930 & 761.640 & -0.290 & 0.00049 & 3.866 & \\
\hline & 21 & $50 \mathrm{~mm}$ 裸面 & 通電 & " & 正常 & $\begin{array}{c}\text { 裸面 } 1 \text { 部 } \\
\text { ピッティグ }\end{array}$ & 0.2 & 750.270 & 751.378 & $3+1.108$ & - & - & ※ \\
\hline \multirow{5}{*}{ 内 } & 22 & " & 否 & $"$ & 凸凹变形 & 裸面全面侵食 & 1.2 & 770.110 & 758.419 & -11.691 & 0.05 & 410.217 & \\
\hline & 23 & " & 通電 & $"$ & 正 常 & $\begin{array}{c}\text { 裸面 } 1 \text { 部 } \\
\text { ピッテング }\end{array}$ & 0.1 & 752.095 & 751.504 & -0.591 & 0.0026 & 20.737 & \\
\hline & 24 & $"$ & 否 & " & 凸凹变形 & 裸面全面侵食 & 1.0 & 739.205 & 729.705 & $\mid-9.500$ & 0.042 & 333.333 & \\
\hline & 89 & 全 面 & 通電 & 良 & 正 & 不 変 & - & 754.530 & 754.349 & -0.181 & 0.0003 & 2.412 & \\
\hline & 90 & $"$ & 否 & $"$ & " & " & - & 763.615 & 763.185 & -0.430 & 0.00073 & 5.740 & \\
\hline \multirow[t]{3}{*}{ 岸 } & 91 & " & 通電 & $"$ & " & " & - & 738.880 & 738.479 & -0.401 & 0.00068 & 5.353 & \\
\hline & 92 & " & 否 & " & " & " & - & 744.230 & 744.269 & +0.039 & - & - & $※$ \\
\hline & 93 & $50 \mathrm{~mm}$ 裸面 & 通電 & $"$ & " & $\begin{array}{l}\text { 裸面 } 1 \text { 部 } \\
\text { ピッティソグ }\end{array}$ & 0.4 & 756.245 & 755.419 & -0.826 & 0.0036 & 28.982 & \\
\hline \multirow[t]{3}{*}{ 壁 } & 94 & " & 否 & " & " & " & 1.55 & 762.210 & 753.753 & -8.457 & 0.0376 & 296.737 & \\
\hline & 95 & $"$ & 通電 & $"$ & " & $"$ & 0.2 & 757.445 & 757.052 & -0.393 & 0.0017 & 41. 368 & \\
\hline & 96 & " & 否 & $"$ & " & " & 1.1 & 747.375 & 740.100 & -7.275 & 0.0324 & 255.263 & \\
\hline
\end{tabular}

\section{※ 科量結果問題点}

テストピース No. 21，92 そおいて埋設時より多い秤量結果が出た。これは埋設時秤量の誤りと思われる。 （埋設時測定方法は不明）なお，No．21，92 は他社にも秤量を依頼同一結果であった。 
表 25 年目 計 測 結 果

昭和 34 年 3 月 11 日測定

\begin{tabular}{|c|c|c|c|c|c|c|c|c|c|c|c|}
\hline \multirow{2}{*}{$\begin{array}{l}\text { 埋 } \\
\text { 設 } \\
\text { 場 } \\
\text { 到 }\end{array}$} & \multirow{2}{*}{$\left|\begin{array}{l}\text { ティト } \\
\text { ピース } \\
\text { No. }\end{array}\right|$} & \multirow{2}{*}{ 染 装 } & \multirow{2}{*}{$\begin{array}{l}\text { 通電 } \\
\text { また通電 } \\
\text { 严 }\end{array}$} & \multirow{2}{*}{ 被覆状況 } & 知 & \multirow{2}{*}{$\left|\begin{array}{c}\text { ピッティング } \\
\text { 深さ最大 } \\
(\mathrm{mm})\end{array}\right|$} & \multicolumn{3}{|c|}{ 計 量 値 $(\mathrm{g})$} & \multirow{2}{*}{$\begin{array}{l}\text { 侵食度 } \\
(\mathrm{mm} / \mathrm{yr})\end{array}$} & \multirow{2}{*}{$\begin{array}{l}\text { 腐食量 } \\
\left(\mathrm{g} / \mathrm{m}^{2} \cdot \mathrm{yr}\right)\end{array}$} \\
\hline & & & & & 外 観 & & 埋設時 & 5 年後 & 差 & & \\
\hline \multirow{3}{*}{ 構 } & 31 & |50mm 裸面 $\mid$ & 通 電 & 正 常 & 全面浅い侵食 & 0.6 & 745.895 & 742.985 & 2.910 & 0.00778 & 61.263 \\
\hline & 40 & " & 否 & " & 全面深い侵食 & 0.55 & 744.555 & 735.675 & 8.880 & 0.02375 & 186.947 \\
\hline & 37 & " & 通 電 & " & 全面浅い侵食 & - & 753.330 & 751.868 & 1. 462 & 0.00391 & 30.779 \\
\hline \multirow{3}{*}{ 内 } & 38 & " & 否 & " & 全面深い侵食 & 0.6 & 766.815 & 755.785 & 11.030 & 0.02951 & 232.211 \\
\hline & 49 & 全 面 & 通 電 & " & 不 变 & - & 758.275 & 758.137 & 0.138 & 0.00014 & 1. 104 \\
\hline & 50 & " & 否 & $"$ & $"$ & - & 758.660 & 758.483 & 0.177 & 0.00018 & 1. 416 \\
\hline \multirow{4}{*}{ 岩 } & 97 & 全 面 & 通 電 & 正 常 & 不 & - & 765.850 & 765.766 & 0.084 & 0.00009 & 0.672 \\
\hline & 98 & " & 否 & $"$ & " & 一 & 739.785 & 739.561 & 0.224 & 0.00023 & 1.792 \\
\hline & 101 & $50 \mathrm{~mm}$ 裸面 & 通 電 & $"$ & 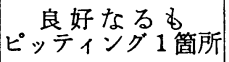 & 0.5 & 749.615 & 749.478 & 0.137 & 0.00037 & 2.884 \\
\hline & 102 & " & 否 & $"$ & 全面深い侵食 & 1.55 & 746.680 & 740.159 & 6.521 & 0.01744 & 137.284 \\
\hline \multirow{3}{*}{ 壁 } & 103 & " & 通 電 & $"$ & 良好 & - & 752.275 & 752.025 & 0.250 & 0.00067 & 5.263 \\
\hline & 104 & " & 否 & $"$ & 全面深い侵食 & 1.4 & 753.630 & 746.949 & 6.681 & 0.01787 & 140.653 \\
\hline & 122 & 全 面 & $"$ & $"$ & 不 变 & - & 743.700 & 743.546 & 0.154 & 0.00016 & 1.232 \\
\hline
\end{tabular}

表 $3 \quad 7$ 年目計 測 結 果

昭和 42 年 5 月 30 日測定

\begin{tabular}{|c|c|c|c|c|c|c|c|c|c|c|c|}
\hline \multirow{2}{*}{$\begin{array}{l}\text { 埋 } \\
\text { 場 } \\
\text { 所 }\end{array}$} & \multirow{2}{*}{$\left|\begin{array}{l}\text { テスト } \\
\text { ピース } \\
\text { No. }\end{array}\right|$} & \multirow{2}{*}{ 塗 装 } & \multirow{2}{*}{ 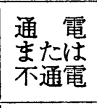 } & \multirow{2}{*}{ 被覆状況 } & \multirow{2}{*}{ 外 観 } & \multirow{2}{*}{$\begin{array}{c}\text { ピッティング } \\
\begin{array}{c}\text { 梁さ最大 } \\
(\mathrm{mm})\end{array}\end{array}$} & \multicolumn{3}{|c|}{ 計 量 值 $(\mathrm{g})$} & \multirow{2}{*}{$\begin{array}{l}\text { 侵食度 } \\
(\mathrm{mm} / \mathrm{yr})\end{array}$} & \multirow{2}{*}{$\left(\mathrm{g} / \mathrm{m}^{2} \cdot \mathrm{yr}\right)$} \\
\hline & & & & & & & 埋設時 & 7 年後 & 差 & & \\
\hline \multirow{5}{*}{ 構 } & 27 & 全 面 & 通 電 & 正 常 & 変 & - & 755.625 & 755. 391 & 0.234 & 0.000017 & 1.337 \\
\hline & 28 & " & 不通電 & " & " & 一 & 754.170 & 753.919 & 0.251 & 0.000018 & 1. 434 \\
\hline & 29 & $50 \mathrm{~mm}$ 裸面 & 通 電 & $"$ & 全面浅い侵食 & 0.3 & 762.515 & 760.269 & 2.248 & 0.00043 & 33.787 \\
\hline & 30 & " & 不通電 & " & 全面深い侵食 & 1.0 & 760.325 & 751.333 & 8.992 & 0.001720 & 133. 149 \\
\hline & 35 & 全 面 & 通 電 & " & 不 変 & - & 745.255 & 745.069 & 0.185 & 0.000013 & 1.059 \\
\hline \multirow[t]{5}{*}{ 内 } & 36 & " & 不通電 & " & " & - & 792.090 & 771.702 & 0.188 & 0.000014 & 1.074 \\
\hline & 55 & $50 \mathrm{~mm}$ 裸面 & 通 電 & " & 全面浅い侵食 & - & 750.920 & 749.557 & 1.368 & 0.000260 & 20.483 \\
\hline & 56 & " & 不通電 & $"$ & 全面深い侵食 & 2.7 & 758,860 & 748.674 & 10.186 & 0.001984 & 153.095 \\
\hline & 105 & 全 面 & 通 電 & " & 不 & - & 758.435 & 758.057 & 0.378 & 028 & 2. 160 \\
\hline & 106 & " & 不通電 & " & " & - & 753.840 & 753.069 & 0.771 & 056 & 4.405 \\
\hline \multirow[t]{3}{*}{ 岸 } & 107 & $"$ & 通 電 & " & " & - & 774.375 & 798.893 & 0.500 & 0.000036 & 3.143 \\
\hline & 108 & " & 不通電 & $"$ & " & - & 759.475 & 758.894 & 0.599 & 0.000043 & 3. 422 \\
\hline & 109 & $50 \mathrm{~mm}$ 裸面 & 通 電 & $"$ & $\begin{array}{c}\text { 良好なる } \\
1 \text { 簡ピッティング }\end{array}$ & 0.3 & 744.903 & 744.603 & 0.302 & 0.000057 & 4. 539 \\
\hline \multirow[t]{3}{*}{ 壁 } & 110 & " & 不通電 & $"$ & 全面深い侵食 & 1.1 & 735.775 & 736.339 & 9.456 & 0.001809 & 142.132 \\
\hline & 111 & $"$ & 通 電 & " & 全面浅い侵食 & - & 971.085 & 770.623 & 0.462 & 0.000088 & 6.943 \\
\hline & 112 & $"$ & 不通電 & $"$ & 全面深い侵食 & 0.8 & 740.120 & 734.872 & 5.238 & 0.001004 & 78.774 \\
\hline
\end{tabular}

ている。なお 5 年目のテストピースの状況を写真 1 に示 す。

\section{6. テストピース防食状況に対するまとめ}

各測定結果のグラフや堀り上げた試験片の表面状態を 観察していえることは, 実際の塗覆装管のコーティング の損傷部を想定して埋設した $50 \mathrm{~mm}$ 裸の試験片に対し 電気防食を行なわない場合には行なった場合の 5〜10 倍 の腐食減量があり, しかも管路として致命的なピッティ ングの深さがかなり大きく, 7 年目で $2.7 \mathrm{~mm}(0.4 \mathrm{~mm} /$ yr）のものもある。したがって管路全部が完全無欠な塗 覆装ならあまり問題ないが，これは現場施工上実際問題 として不可能に近いものであり，しばしば起こり得る管 路の施工中のコーティング損傷部あるいは現場塗覆装部
分の損傷部の腐食防止には，電気防食がきわめて有効な ことを示す。

\section{7. 保守篦理}

前回の報告に今後の問題としてあげられた事項に関し ては,

a) 交通車輛の増大, 上下水道, 通信線等の埋設工事 などの影響は顕著なものがあり，このために（c）に記 した流電陽極の追加を行なった。

b ）保守管理は毎年 1 回の電位測定, 毎月 1 回程度の 巡視管理を夷施し，その結果に基ついて（a ）の修正を 加えている。

c ）大協油化線，岸壁線などには $\mathrm{Mg}$ 陽極 17-D 型 を 27 本， 2 本組ないし 3 本組として数個所に分け，昭 


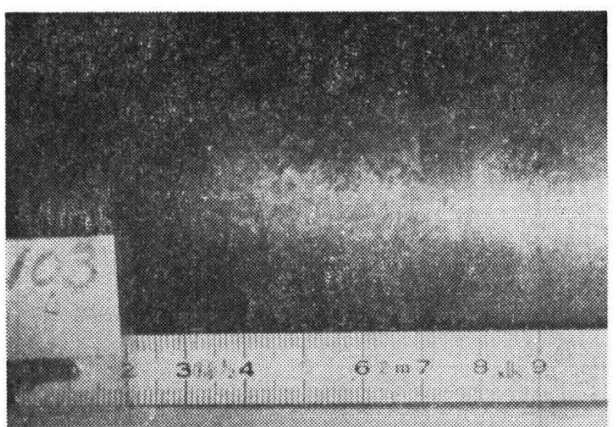

$50 \mathrm{~mm}$ 裸通電

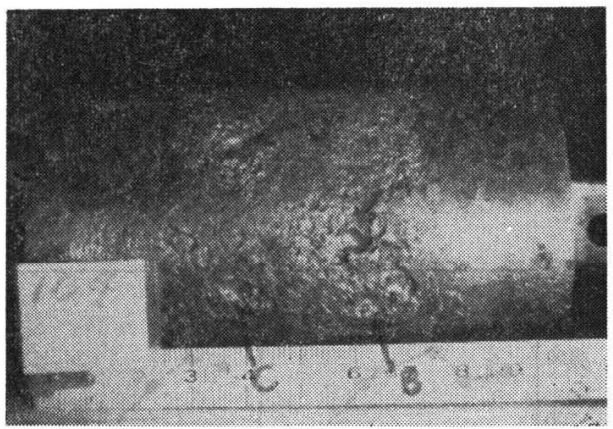

$50 \mathrm{~mm}$ 裸不通電

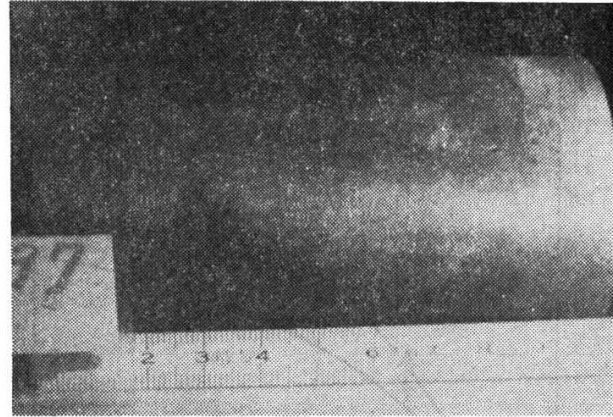

全面淮装通電

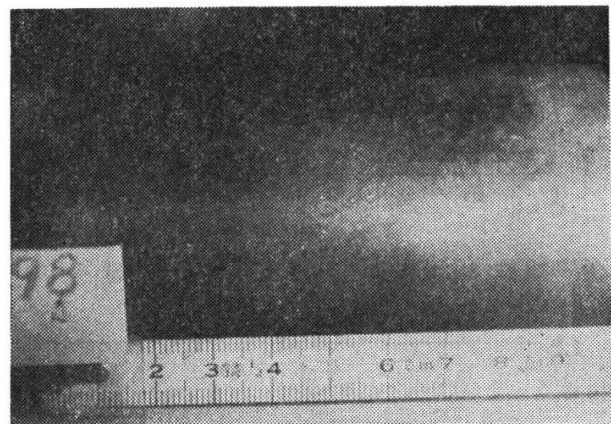

全面塗装不通電

写真 1 a テストピース写真（5年目）（岸壁側）

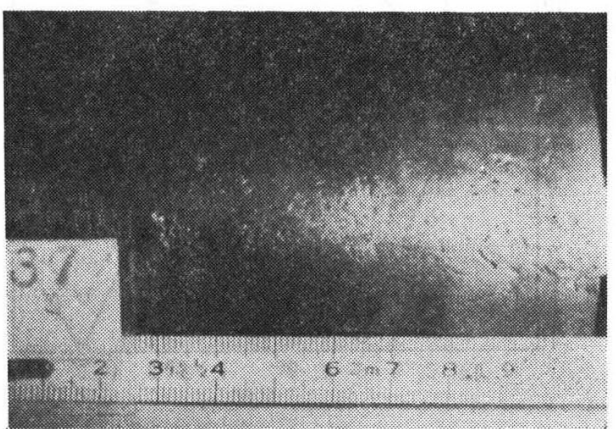

$50 \mathrm{~mm}$ 裸通電

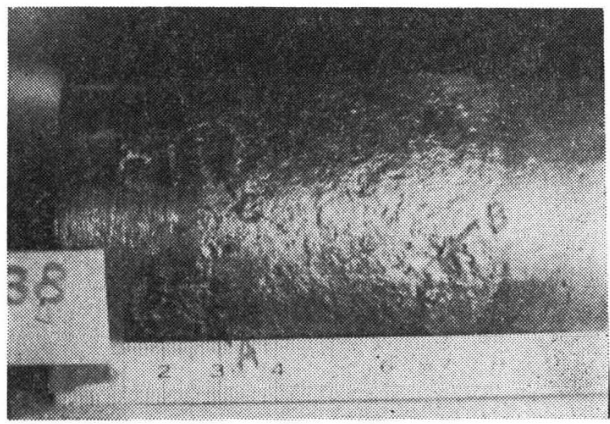

$50 \mathrm{~mm}$ 裸不通電

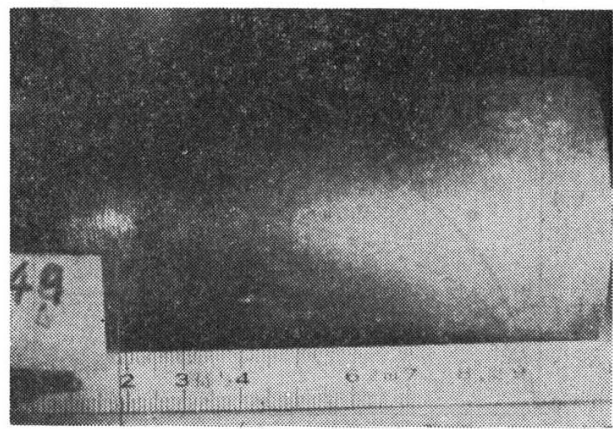

全面塗装通電

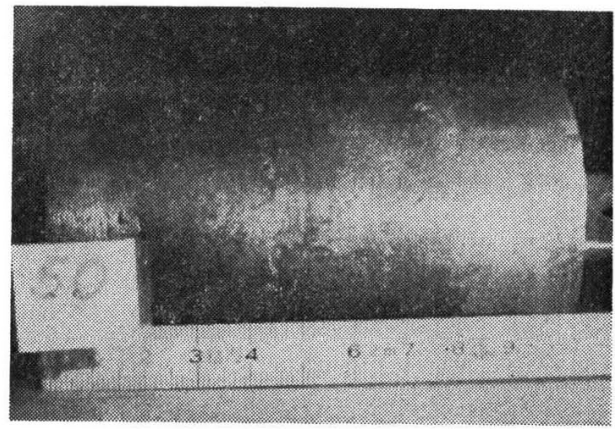

全面浴装不通電

写真 1 b 日本合成ゴム構内 


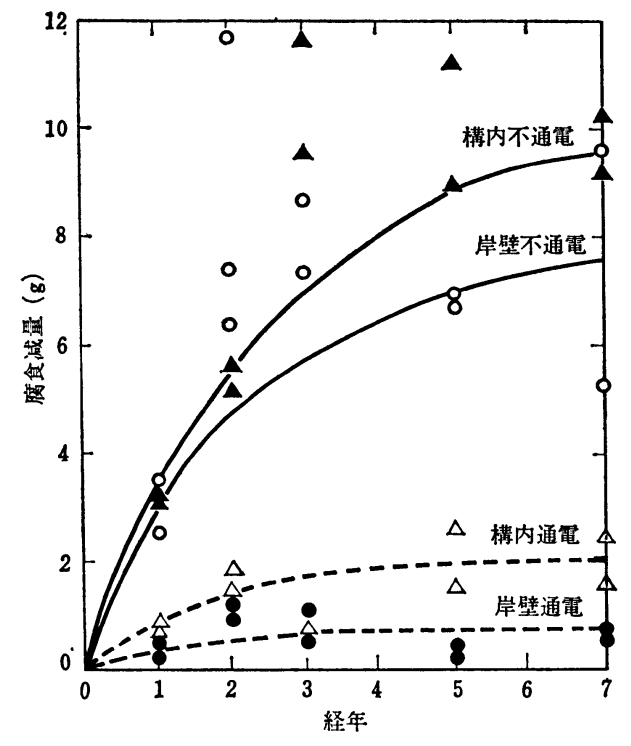

図 3 テストピースの経時的腐食減量 $50 \mathrm{~mm}$ 裸面 (約 $37 \%$ 裸)

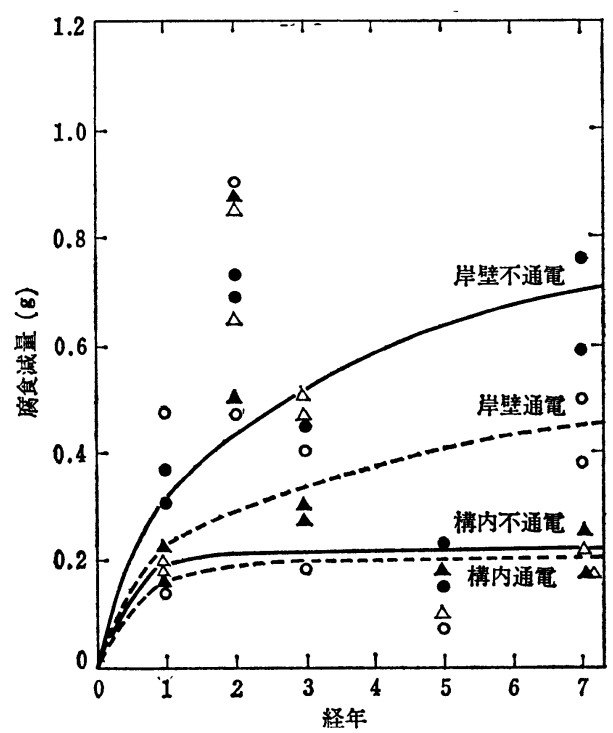

図 4 テストピースの経時的腐食減量 （全面㳂装）

和 42 年 10 月に追加設置した。

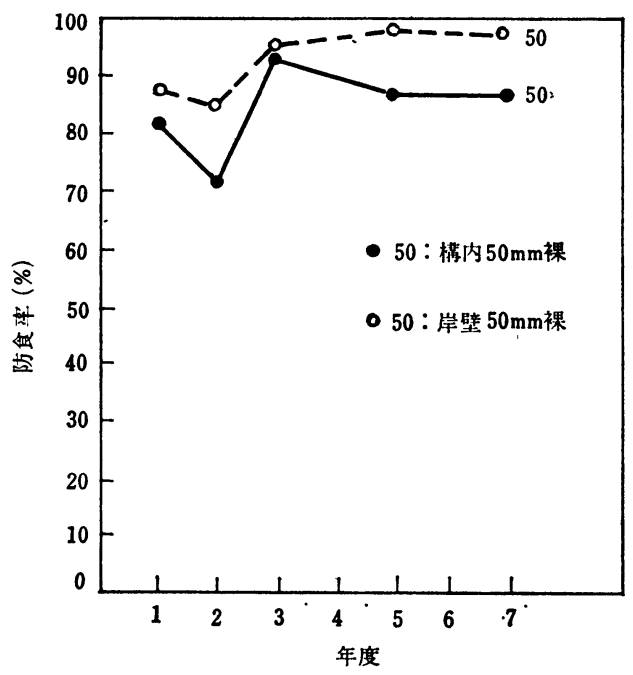

図 5 各年度におけるテストピース通電効果

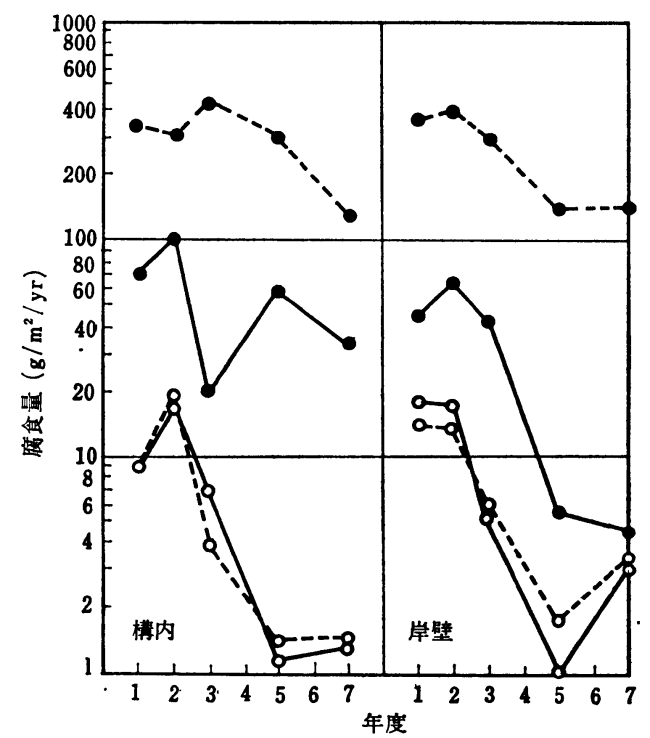

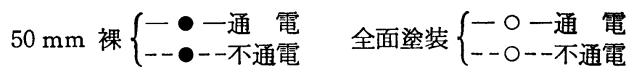
図 6 各年度におけるテストピース腐食量

考支献

(昭和 44 年 7 月 1 日受理)

1）井上泰应: 防蝕技術, 12, No. 1，12 18 (1963) 